\title{
The concept of dental vulnerability in Brazil
}

\section{O conceito de vullnerabilidade odontológica no Brasil \\ El concepto de vulnerabilidad dental en Brasil}

Danielle da Costa Palacio ORCID: https://orcid.org/0000-0003-4184-4464 Hospital Israelita Albert Einstein, Brazil E-mail: daniellepalacio@yahoo.com.br

Flavio Rebustini ORCID: https://orcid.org/0000-0002-3746-3266

Universidade de São Paulo, Brazil E-mail: flrebustini@gmail.com

Daniele Boina de Oliveira

ORCID: https://orcid.org/0000-0002-1196-568X Hospital Israelita Albert Einstein, Brazil

E-mail: dani_boina@hotmail.com

João Peres Neto

ORCID: https://orcid.org/0000-0002-6988-5826 Hospital Israelita Albert Einstein, Brazil E-mail: joao.peres@einstein.br

Thais Paragis Sanchez

ORCID: https://orcid.org/0000-0003-3418-7689 Hospital Israelita Albert Einstein, Brazil

E-mail: thais.sanchez@einstein.br

Ana Carolina Cintra Nunes Mafra

ORCID: https://orcid.org/0000-0001-9004-7176 Hospital Israelita Albert Einstein, Brazil

E-mail: ana.mafra@einstein.br

Daiana Bonfim

ORCID: https://orcid.org/0000-0003-0591-0495 Hospital Israelita Albert Einstein, Brazil

E-mail: bonfim.daiana@einstein.br

João Luiz Miraglia

ORCID: https://orcid.org/0000-0002-4788-6254 Hospital Israelita Albert Einstein, Brazil

E-mail: joao.miraglia@einstein.br

Fernanda Maria Rovai Bado

ORCID: https://orcid.org/0000-0002-7974-5456

Universidade Estadual de Campinas, Brazil

E-mail: fmrbado@gmail.com

Wander Barbieri

ORCID: https://orcid.org/0000-0001-6124-5771

Hospital Israelita Albert Einstein, Brazil

E-mail: wander.barbieri@einstein.br

Valmir Vanderlei Gomes Filho

ORCID: https://orcid.org/0000-0002-4219-6465

Hospital Israelita Albert Einstein, Brazil E-mail: valmir.filho@einstein.br

Antonio Carlos Pereira

ORCID: https://orcid.org/0000-0003-1703-8171

Universidade Estadual de Campinas, Brazil

E-mail: apereira@fop.unicamp.br

\begin{abstract}
Objective: To present a concept of dental vulnerability based on the opinion of oral health professionals in Brazil. Methods: A cross-sectional study performed in two stages: preparation of a questionnaire by literature search and its application with oral health specialists. The data were analyzed by means of Bardin technique and descriptive analysis. Results: A total of 188 professionals from all regions of Brazil responded to the questionnaire. The answers were classified into seven dimensions, conceptualizing dental vulnerability as a set of social, structural, overall health, mental, and oral health factors, in addition to factors involving the health services and public management that influence the health-disease process dynamic. Conclusion: The concept of dental vulnerability produced from the opinions of the professionals from different regions of Brazil allows advancement to new studies on the theme and the
\end{abstract}


development of instruments aiming to measure the phenomenon.

Keywords: Oral health; Health vulnerability; Population; Questionnaire.

\section{Resumo}

Objetivo: Apresentar um conceito de vulnerabilidade odontológica a partir da opinião dos profissionais de saúde bucal do Brasil. Métodos: Estudo transversal realizado em duas etapas: construção de questionário por meio de levantamento de literatura e sua aplicação em especialistas de saúde bucal. Os dados foram analisados por meio da técnica de Bardin e análise descritiva. Resultados: Responderam ao questionário 188 profissionais de todas as regiões do Brasil. As respostas foram categorizadas em sete dimensões, conceituando vulnerabilidade odontológica como um conjunto de fatores sociais, estruturais, de saúde geral, mental e bucal, além de fatores envolvendo os serviços de saúde e a gestão pública que influenciam a dinâmica do processo saúde-doença. Conclusão: O conceito de vulnerabilidade odontológica produzido a partir da opinião dos profissionais de diferentes regiões do Brasil possibilita avançar em novos estudos sobre o tema e no desenvolvimento de instrumentos que buscam mensurar o fenômeno.

Palavras-chave: Saúde bucal; Vulnerabilidade em saúde; População; Questionário.

\section{Resume}

Objetivo: Presentar un concepto de vulnerabilidad dental con base en la opinión de los profesionales de salud bucal de Brasil. Métodos: Estudio transversal realizado en dos etapas: construcción de un cuestionario mediante investigación en la literatura y su aplicación a especialistas en salud bucal. Los datos se analizaron mediante la técnica de Bardin y análisis descriptivo. Resultados: 188 profesionales de todas las regiones de Brasil respondieron al cuestionario. Las respuestas se categorizaron en siete dimensiones, conceptualizando la vulnerabilidad dental como un conjunto de factores sociales, estructurales, de salud general, mental y bucal, además de factores que abarcan los servicios de salud y la gestión pública que inciden en la dinámica del proceso salud-enfermedad. Conclusión: El concepto de vulnerabilidad dental producido con base en la opinión de profesionales de diferentes regiones de Brasil permite avanzar en nuevos estudios sobre el tema y en el desarrollo de instrumentos que buscan medir el fenómeno.

Palabras clave: Salud bucal; Vulnerabilidad en salud; Población; Cuestionario.

\section{Introduction}

Oral Health Teams (OHT) that work in Primary Health Care (PHC) with the Family Health Strategy (FHS) experience the challenge of the high demand for dental care and the low possibility of supply, due to the low ratio of OHT available in the territory (Pucca Junior et al., 2020). Thus, the process of choice and prioritization of the user who will have access to the service can be carried out by institutional factors, when filed in the services, but also, often through decision-making based on the judgment of the professionals (Emílio Prado da Fonseca, Fonseca, \& Meneghim, 2017). In this context, the inclusion of dental vulnerability identification is important to ensure equity. However, the concept of dental vulnerability is still discussed very little from the perspective of oral health professionals in Brazil.

Questions about the use and limits of the concept of risk led to discussions about vulnerability, and Ayres is as one of the main references on the subject. The concept of vulnerability is now understood as a grouping of risk factors resulting from the absence of essential resources for well-being, whether material, social, behavioral, or environmental, i.e., the chance of exposure to illness, influenced by interdependent factors interacting individually, collectively, socially, programmatically, and by protective resources in the health-disease process (Ayres, Calazans, Filho, \& França-Júnior, 2003; Dimenstein \& Cirilo Neto, 2020).

The circumstances for classifying individuals or groups as vulnerable are admittedly complex and take into account unique risk factors and biological influences, as well as the social context. Thus, vulnerability can be used to better understand health practices as social and historical practices, which require working with different sectors of society and transdisciplinary (Ayres et al., 2003; Dimenstein \& Cirilo Neto, 2020).

Considering that health is closely related to social determinants (Loh, 2017), as well as to the high prevalence of oral diseases in the world (Peres et al., 2019), monitoring risk factors and oral health determinants provides information on populations and needs, preventive practices and health system priorities (Peres et al., 2019).

It is recognized that oral health directly impacts the individual's performance of daily activities and quality of life 
(Bulgareli et al., 2018). Oral diseases and their consequences disproportionately affect individuals and vulnerable and disadvantaged groups (Watt, Venturelli, \& Daly, 2019), causing functional, social, and psychological adverse effects (Bulgareli et al., 2018). Socioeconomic conditions are associated with the prevalence and severity of oral diseases, indicating limited access to dental services and an increased risk of oral problems (Watt et al., 2019). Moreover, smoking, very low income, alcohol use, difficulty in chewing and speaking, need for treatment, dissatisfaction with appearance, impairment in affective relationships, history of previous oral and systemic diseases, as well as the absence of roads, water, and electricity aggravate oral conditions and are considered risk factors (Emílio P. Da Fonseca, Frias, Mialhe, Pereira, \& Meneghim, 2017).

However, some authors also report protective factors, such as perception of oral health, school attendance, dental brushing, use of dental floss, consumption of fruits and vegetables, periodic replacement of dental prostheses, selfexamination, and consultation with the dentist (Emílio P. Da Fonseca et al., 2017).

Thus, the challenge of translating dental vulnerability through a concept goes through the inclusion of a set of biological, social, physical, and emotional conditions that determine the way of living, producing health, and becoming ill (Paim, Travassos, Almeida, Bahia, \& Macinko, 2011). Understanding a concept so heterogeneous by regional local influences in Brazil, may help in the process of building tools for the organization of dental demand, and the search for a more equitable and remedial oral health supply in PHC.

Thus, this project aims to prepare a concept of dental vulnerability based on the opinion of oral health professionals from different Brazilian regions.

\section{Methodology}

This is a cross-sectional study conducted in the five regions of Brazil (South, Southeast, Northeast, Midwest, and North), with a convenience sample composed of 188 specialists (dental surgeons, oral health technicians, and dental students), of both sexes, over 18 years of age, who digitally signed the Informed Consent Form (ICF) and completed the survey questionnaire received.

The study was approved by the Research Ethics Committee of the Municipal Department of Health of São Paulo (CAE 97371218.4.0000.0086).

The study was carried out in two phases:

\section{Phase 1: Development of the questionnaire}

A bibliographic review on dental vulnerability was carried out from 2015 to 2019 on the MESH-Pubmed platform. The following descriptors were combined and used: Oral Health; Vulnerability Analysis; Social Vulnerability; Vulnerability Study; Health Vulnerability; Risk Groups; Risk; Risk Factors; Dental Care; Epidemiologic Factors; Health Services Accessibility; Equity in Access to Health Services; Universal Access to Health Care Services; Patient Health Questionnaire; Primary Health Care; Public Health; Dentistry, Dental Health Surveys; Health Status Indicators; Patient Health; Questionnaire.

Forty articles were selected, and after reading, factors cited in the studies as relevant to dental vulnerability were identified. A questionnaire was built on the RedCap ${ }^{\circledR}$ platform, based on the identified factors, with closed and open questions for oral health specialists to give their opinion on the "dental vulnerability" theme.

The questionnaire was composed of three topics:

Topic 1: characterization information on the specialists: sex, age, region, and state of residence, profession, professional experience, and educational level. For the professional experience item, more than one field could be filled in.

Topic 2: a list of 16 relevant items to influence dental vulnerability, so that the experts could tick all those they considered important by asking: "If you had to measure dental vulnerability, what factors would you consider?" The items that 
could be selected were access to health services in the last year; access to dental services in the last year; income; being employed; use of drugs; use of alcoholic beverages; having diabetes; having reflux; having difficulty eating (chewing); access to a toothbrush; access to dental floss; habit of eating sweets; access to oral health information; already having had a toothache; being ashamed of the appearance of their teeth; and attending school.

Topic 3: open questions related to dimensions: social factors, infrastructure, general health, and psychological factors, so that experts could discuss the items they considered important to measure dental vulnerability.

\section{Phase 2: Questionnaire application}

The snowball method was used (Goodman, 1961) to apply the questionnaire. The developed questionnaire was distributed to specialists from all regions of Brazil, including the Federal District, through the WhatsApp® application and in e-mail groups composed of oral health professionals. The collection was carried out from December 3 to 20, 2018, and average completion time was 5 minutes.

After finishing the questionnaire, all responses obtained in the free text fields were organized and grouped into seven dimensions, including the four initially proposed by the questionnaire.

\section{Data analysis}

All pieces of information obtained in the open questions were analyzed according to Bardin's content analysis (Bardin, 1977). To ensure reliability of the classification performed through the content analysis, four external and impartial judges were invited to review credibility of the categories established by the researchers (Korstjens \& Moser, 2018).

For quantitative analysis, when categorical, the variables were described by absolute and relative frequency; and when continuous, by mean, standard deviation, and range. The distribution of specialists by state was visually represented on a map. The frequency of closed answers was shown on a table and on a bar graph by means of percentages of answers and $95 \%$ confidence intervals $(95 \% \mathrm{CI})$. A figure was used to present the final dimensions. The R software, version 3.6.1, with Map tools package was used.

\section{Results}

A total of 188 participants from all regions of Brazil answered the questionnaire, and the region with the highest number of answers was the Southeast with 67\% (Figure 1). 
Figure 1. Percentage of specialists per Brazilian state participating in the study. Brazil, 2019.

\section{Responses per state (\%).}

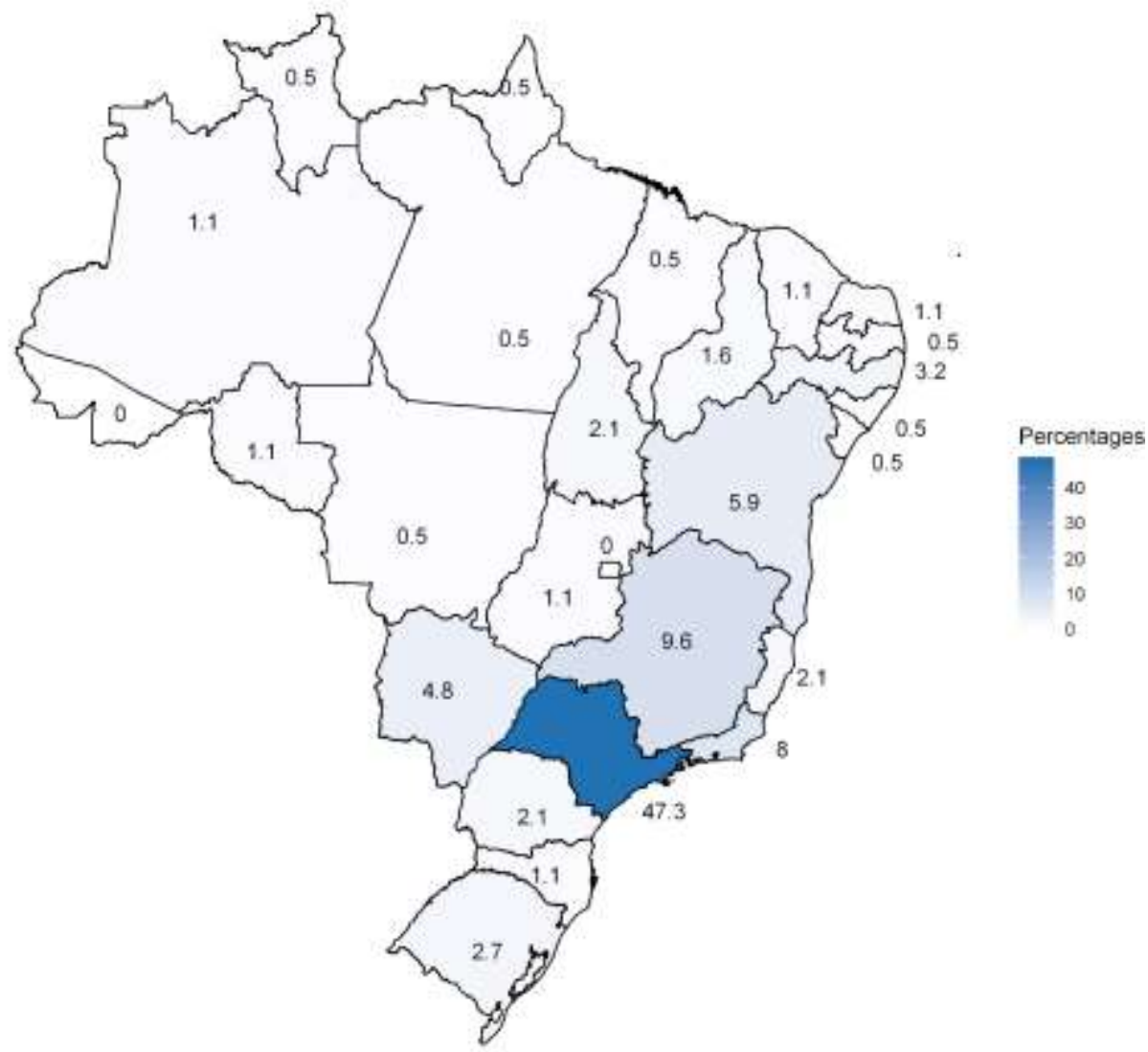

Source: http://mapas.mma.gov.br/i3geo/datadownload.htm.

The participants were mostly female (78.7\%), dental surgeons (86.2\%), with completed specialization (51.6\%), and experience in a Primary Care Unit $(79.8 \%)$, followed by private practice $(73.9 \%)$, since in the questionnaire more than one professional experience could be informed (Table 1). 
Table 1. Profile of the study participants. Brazil, 2019.

\begin{tabular}{ll}
\hline Characteristics & Frequencies (n=188) \\
\hline Age (years)* & $39.1 \pm 8.9(20.0-62.0)$ \\
Female & $78.7 \%$ \\
Profession & \\
Dental surgeon & $86.2 \%$ \\
Oral health technician & $5.9 \%$ \\
Oral health assistant & $3.2 \%$ \\
Dental school student & $2.1 \%$ \\
Other professionals & $2.7 \%$ \\
Schooling & \\
Complete doctorate degree & $5.9 \%$ \\
Complete master's degree & $16.0 \%$ \\
Complete college & $16.0 \%$ \\
Incomplete college & $3.7 \%$ \\
Complete specialization & $51.6 \%$ \\
Technical education & $3.2 \%$ \\
Complete high school & $3.7 \%$ \\
Professional experience & \\
Primary Care Unit & $79.8 \%$ \\
Private office & $73.9 \%$ \\
Lecturer & $16.5 \%$ \\
Researcher & $19.1 \%$ \\
Region & \\
Midwest & $6.4 \%$ \\
Northeast & $15.4 \%$ \\
North & $5.3 \%$ \\
Southeast & $67.0 \%$ \\
South & $5.9 \%$ \\
\hline & \\
\hline
\end{tabular}

* Continuous datum, mean, standard deviation, and range. Source: Authors.

Regarding the most cited factors by the respondents, the access to information on oral health $(70.7 \%)$, income (68.6\%), and access to dental services in the last year (66.5\%) stood out. The less mentioned factors were having reflux (23.9\%), attending school (26.1\%), and having diabetes (36.7\%) (Figure 2, Table 2). 
Research, Society and Development, v. 10, n. 9, e30310917792, 2021

(CC BY 4.0) | ISSN 2525-3409 | DOI: http://dx.doi.org/10.33448/rsd-v10i9.17792

Figure 2. Factors considered associated with dental vulnerability (\% and 95\%CI). Brazil, 2019.

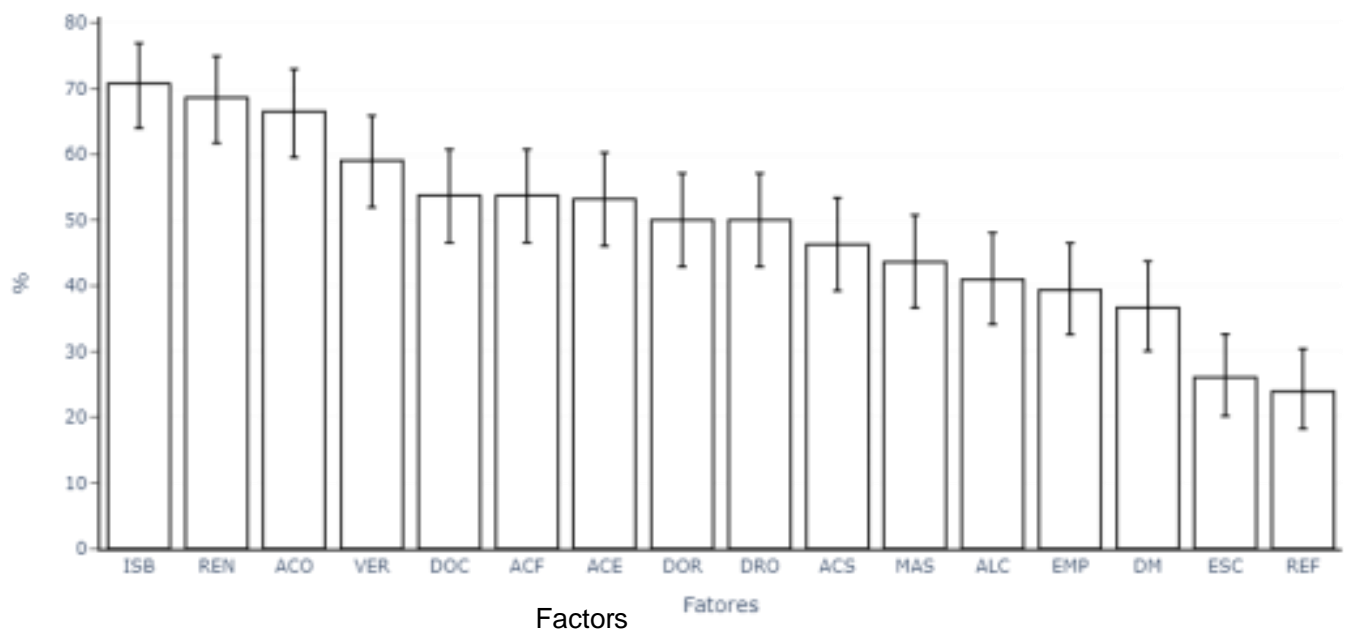

Legend: ISB: Access to oral health information; REN: Income; ACO: Access to dental services in the last year; VER: Embarrassment due to tooth-related appearance; ACF: Access to dental floss; DOC: Habit of eating sweets; ACE: Access to toothbrush; DRO: Use of drugs; DOR: Already having had a toothache; ACS: Access to health services in the last year; MAS: Having difficulty in chewing; ALC: Use of alcoholic beverages; EMP: Be employed; DM: Have diabetes; ESC: Attend school; REF: Have reflux. Source: Authors. 
Table 2. Comparison of the items that compose the concept of dental vulnerability among the Brazilian regions. Brazil, 2019.

\begin{tabular}{|c|c|c|c|c|c|c|}
\hline $\begin{array}{c}\text { Evaluated } \\
\text { Factors }\end{array}$ & $\begin{array}{l}\text { Midwest } \\
(\mathrm{N}=12)\end{array}$ & $\begin{array}{l}\text { Northeast } \\
\qquad(\mathbf{N}=\mathbf{2 9})\end{array}$ & North $(\mathrm{N}=10)$ & $\begin{array}{c}\text { Southeast } \\
(\mathrm{N}=126)\end{array}$ & South $(\mathbf{N}=11)$ & $\begin{array}{c}\text { Brazil } \\
(\mathrm{N}=188)\end{array}$ \\
\hline $\begin{array}{c}\text { Access to } \\
\text { information } \\
\text { about oral } \\
\text { health }\end{array}$ & $\begin{array}{c}91.7 \\
(61.5-99.8)\end{array}$ & $\begin{array}{c}75.9 \\
(56.5-89.7)\end{array}$ & $\begin{array}{c}90.0 \\
(55.5-99.7)\end{array}$ & $\begin{array}{c}65.9 \\
(56.9-74.1)\end{array}$ & $\begin{array}{c}72.7 \\
(39.0-94.0)\end{array}$ & $\begin{array}{c}70.7 \\
(63.7-77.1)\end{array}$ \\
\hline Income & $\begin{array}{c}66.7 \\
(34.9-90.1) \\
\end{array}$ & $\begin{array}{c}65.5 \\
(45.7-82.1) \\
\end{array}$ & $\begin{array}{c}90.0 \\
(55.5-99.7) \\
\end{array}$ & $\begin{array}{c}67.5 \\
(58.5-75.5)\end{array}$ & $\begin{array}{c}72.7 \\
(39.0-94.0) \\
\end{array}$ & $\begin{array}{c}68.6 \\
(61.5-75.2) \\
\end{array}$ \\
\hline $\begin{array}{c}\text { Access to } \\
\text { dental } \\
\text { services in the } \\
\text { last year } \\
\end{array}$ & $\begin{array}{c}58.3 \\
(27.7-84.8)\end{array}$ & $\begin{array}{c}75.9 \\
(56.5-89.7)\end{array}$ & $\begin{array}{c}70.0 \\
(34.8-93.3)\end{array}$ & $\begin{array}{c}64.3 \\
(55.3-72.6)\end{array}$ & $\begin{array}{c}72.7 \\
(39.0-94.0)\end{array}$ & $\begin{array}{c}66.5 \\
(59.3-73.2)\end{array}$ \\
\hline $\begin{array}{c}\text { Be ashamed } \\
\text { of tooth- } \\
\text { related } \\
\text { appearance } \\
\end{array}$ & $\begin{array}{c}58.3 \\
(27.7-84.8)\end{array}$ & $\begin{array}{c}69.0 \\
(49.2-84.7)\end{array}$ & $\begin{array}{c}40.0 \\
(12.2-73.8)\end{array}$ & $\begin{array}{c}57.1 \\
(48.0-65.9)\end{array}$ & $\begin{array}{c}72.7 \\
(39.0-94.0)\end{array}$ & $\begin{array}{c}59.0 \\
(51.7-66.1)\end{array}$ \\
\hline $\begin{array}{c}\text { Access to } \\
\text { dental floss } \\
\end{array}$ & $\begin{array}{c}66.7 \\
(34.9-90.1) \\
\end{array}$ & $\begin{array}{c}58.6 \\
(38.9-76.5) \\
\end{array}$ & $\begin{array}{c}50.0 \\
(18.7-81.3) \\
\end{array}$ & $\begin{array}{c}51.6 \\
(42.5-60.6) \\
\end{array}$ & $\begin{array}{c}54.5 \\
(23.4-83.3) \\
\end{array}$ & $\begin{array}{c}53.7 \\
(46.3-61.0) \\
\end{array}$ \\
\hline $\begin{array}{c}\text { Habit of } \\
\text { eating sweets }\end{array}$ & $\begin{array}{c}66.7 \\
(34.9-90.1) \\
\end{array}$ & $\begin{array}{c}48.3 \\
(29.4-67.5) \\
\end{array}$ & $\begin{array}{c}60.0 \\
(26.2-87.8) \\
\end{array}$ & $\begin{array}{c}51.6 \\
(42.5-60.6) \\
\end{array}$ & $\begin{array}{c}72.7 \\
(39.0-94.0) \\
\end{array}$ & $\begin{array}{c}53.7 \\
(46.3-61.0) \\
\end{array}$ \\
\hline $\begin{array}{l}\text { Access to a } \\
\text { toothbrush }\end{array}$ & $\begin{array}{c}58.3 \\
(27.7-84.8) \\
\end{array}$ & $\begin{array}{c}58.6 \\
(38.9-76.5) \\
\end{array}$ & $\begin{array}{c}50.0 \\
(18.7-81.3) \\
\end{array}$ & $\begin{array}{c}50.8 \\
(41.7-59.8) \\
\end{array}$ & $\begin{array}{c}63.6 \\
(30.8-89.1) \\
\end{array}$ & $\begin{array}{c}53.2 \\
(45.8-60.5) \\
\end{array}$ \\
\hline Use of drugs & $\begin{array}{c}58.3 \\
(27.7-84.8) \\
\end{array}$ & $\begin{array}{c}55.2 \\
(35.7-73.6) \\
\end{array}$ & $\begin{array}{c}30.0 \\
(6.7-65.2) \\
\end{array}$ & $\begin{array}{c}48.4 \\
(39.4-57.5) \\
\end{array}$ & $\begin{array}{c}63.6 \\
(30.8-89.1) \\
\end{array}$ & $\begin{array}{c}50.0 \\
(42.6-57.4) \\
\end{array}$ \\
\hline $\begin{array}{c}\text { Already } \\
\text { having had a } \\
\text { toothache }\end{array}$ & $\begin{array}{c}25.0 \\
(5.5-57.2)\end{array}$ & $\begin{array}{c}51.7 \\
(32.5-70.6)\end{array}$ & $\begin{array}{c}50.0 \\
(18.7-81.3)\end{array}$ & $\begin{array}{c}50.8 \\
(41.7-59.8)\end{array}$ & $\begin{array}{c}63.6 \\
(30.8-89.1)\end{array}$ & $\begin{array}{c}50.0 \\
(42.6-57.4)\end{array}$ \\
\hline $\begin{array}{c}\text { Access to } \\
\text { health } \\
\text { services in the } \\
\text { last year }\end{array}$ & $\begin{array}{c}33.3 \\
(9.9-65.1)\end{array}$ & $\begin{array}{c}44.8 \\
(26.4-64.3)\end{array}$ & $\begin{array}{c}70.0 \\
(34.8-93.3)\end{array}$ & $\begin{array}{c}45.2 \\
(36.4-54.3)\end{array}$ & $\begin{array}{c}54.5 \\
(23.4-83.3)\end{array}$ & $\begin{array}{c}46.3 \\
(39.0-53.7)\end{array}$ \\
\hline $\begin{array}{c}\text { Have } \\
\text { difficulty } \\
\text { chewing } \\
\end{array}$ & $\begin{array}{c}50.0 \\
(21.1-78.9)\end{array}$ & $\begin{array}{c}34.5 \\
(17.9-54.3)\end{array}$ & $\begin{array}{c}40.0 \\
(12.2-73.8)\end{array}$ & $\begin{array}{c}43.7 \\
(34.8-52.8)\end{array}$ & $\begin{array}{c}63.6 \\
(30.8-89.1)\end{array}$ & $\begin{array}{c}43.6 \\
(36.4-51.0)\end{array}$ \\
\hline $\begin{array}{c}\text { Use of } \\
\text { alcoholic } \\
\text { beverages }\end{array}$ & $\begin{array}{c}41.7 \\
(15.2-72.3)\end{array}$ & $\begin{array}{c}55.2 \\
(35.7-73.6)\end{array}$ & $\begin{array}{c}20.0 \\
(2.5-55.6)\end{array}$ & $\begin{array}{c}37.3 \\
(28.9-46.4)\end{array}$ & $\begin{array}{c}63.6 \\
(30.8-89.1)\end{array}$ & $\begin{array}{c}41.0 \\
(33.9-48.3)\end{array}$ \\
\hline Be employed & $\begin{array}{c}50.0 \\
(21.1-78.9)\end{array}$ & $\begin{array}{c}41.4 \\
(23.5-61.1)\end{array}$ & $\begin{array}{c}30.0 \\
(6.7-65.2)\end{array}$ & $\begin{array}{c}38.9 \\
(30.3-48.0)\end{array}$ & $\begin{array}{c}36.4 \\
(10.9-69.2)\end{array}$ & $\begin{array}{c}39.4 \\
(32.3-46.7)\end{array}$ \\
\hline Have diabetes & $\begin{array}{c}50.0 \\
(21.1-78.9) \\
\end{array}$ & $\begin{array}{c}37.9 \\
(20.7-57.7) \\
\end{array}$ & $\begin{array}{c}40.0 \\
(12.2-73.8)\end{array}$ & $\begin{array}{c}34.9 \\
(26.6-43.9)\end{array}$ & $\begin{array}{c}36.4 \\
(10.9-69.2) \\
\end{array}$ & $\begin{array}{c}36.7 \\
(29.8-44.0)\end{array}$ \\
\hline Attend school & $\begin{array}{c}25.0 \\
(5.5-57.2) \\
\end{array}$ & $\begin{array}{c}34.5 \\
(17.9-54.3) \\
\end{array}$ & $\begin{array}{c}40.0 \\
(12.2-73.8) \\
\end{array}$ & $\begin{array}{c}23.0 \\
(16.0-31.4) \\
\end{array}$ & $\begin{array}{c}27.3 \\
(6.0-61.0) \\
\end{array}$ & $\begin{array}{c}26.1 \\
(19.9-33.0) \\
\end{array}$ \\
\hline Have reflux & $\begin{array}{c}41.7 \\
(15.2-72.3) \\
\end{array}$ & $\begin{array}{c}27.6 \\
(12.7-47.2) \\
\end{array}$ & $\begin{array}{c}10.0 \\
(0.3-44.5) \\
\end{array}$ & $\begin{array}{c}22.2 \\
(15.3-30.5)\end{array}$ & $\begin{array}{c}27.3 \\
(6.0-61.0) \\
\end{array}$ & $\begin{array}{c}23.9 \\
(18.0-30.7) \\
\end{array}$ \\
\hline
\end{tabular}

\% (95\%CI) - Source: Research Data's

When analyzing in detail the factors considered being associated with dental vulnerability, it is possible to notice a variety among the prevalence factors in each region (Table 2). The item "access to information on oral health" was cited by $91.7 \%$ of respondents in the Midwest region and 65.9\% in the Southeast region. For the item "income," in the North region, it was cited by $90 \%$ of specialists, while the Southeast (67.5\%), Northeast (65.5\%), and Midwest (66.7\%) had a similar distribution. The item "access to dental services in the last year" was more prevalent in the Northeast region (75.9\%), and less in the Midwest region (58.3\%), not being significant discrepant among Brazilian regions (Table 2).

In addition to the pre-defined items, participants were able to discuss in open fields other items they considered important for dental vulnerability. In this process, some items were modified in dimensions, after analysis of the disagreements by the four independent judges: lack of training of oral health teams for promotion and prevention; lack of integration of oral health teams with primary care teams; public policies for oral health; few oral health assistants; regional differences; pollution; 
cognitive deficit; low coverage of care; equipment stopped for lack of maintenance; insufficient physical space for dental office, lack of ventilation in dental offices, lack of investment in health, hours of care at the Brazilian Unified Health System (SUS), having oral health teams in the municipality, insufficient human resources, remuneration of professionals, low quality materials in health care units, and presence of family health strategy.

The answers obtained at the end of the questionnaire extrapolated the four dimensions initially proposed, requiring the construction of three new dimensions. Thus, all items mentioned were categorized within seven dimensions, which define dental vulnerability (Figure 3).

Figure 3. Representation of the seven final dimensions with their respective items.

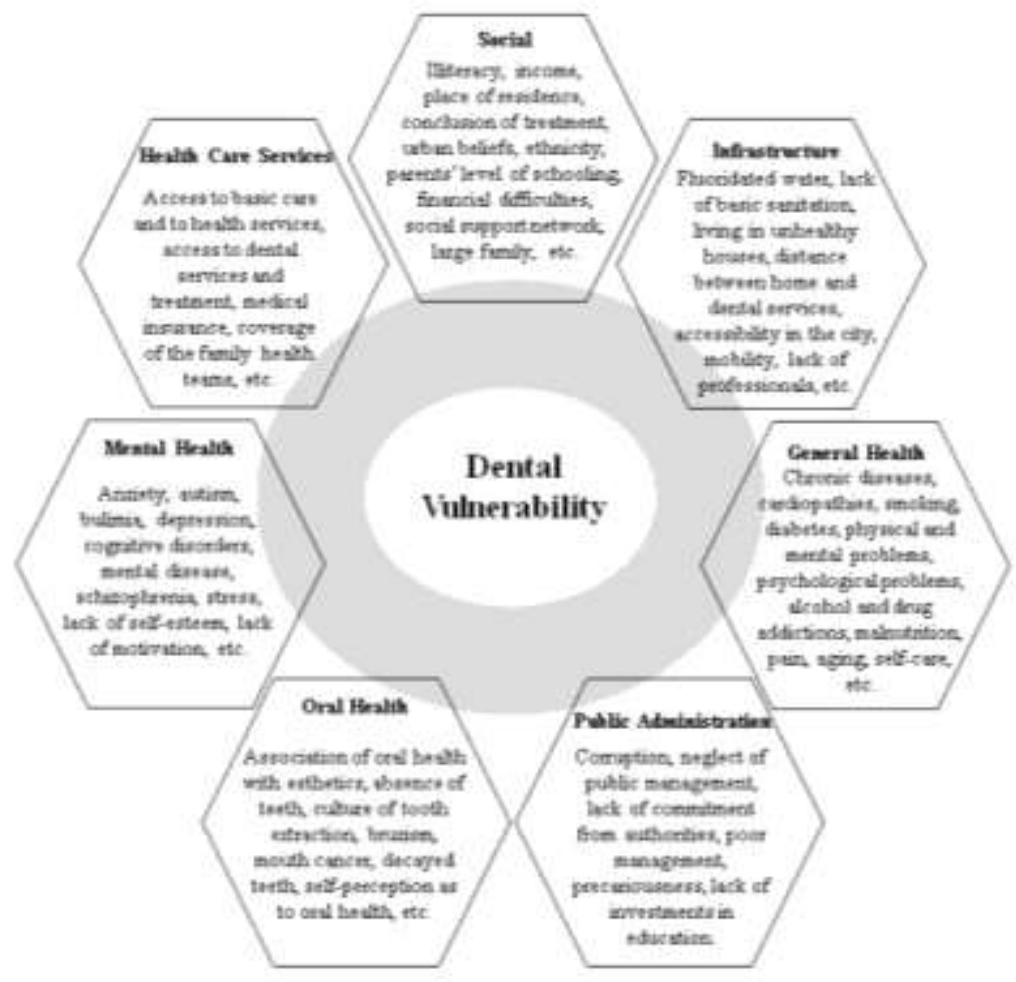

Source: Authors.

The social dimension agreed in all regions on the item "income" as an important factor to configure dental vulnerability. Social factors, such as "the family, social living conditions, among others" were mentioned by some experts in the open questions. In addition, other social factors were cited, such as "vulnerabilities related to gender and ethnicity" (specialist 46, Midwest), "mother's schooling level" (specialist 19, Southeast), "family structure" (specialist 228, Southeast), and "social condition, employment, and income are also determinants of vulnerability" (specialist 53, Northeast).

Analyzing the infrastructure dimension, the influence of factors, such as "lack of basic sanitation and living in unhealthy residences" was highlighted (Southeast, specialist 153), in addition to the lack of professionals trained to meet the demand: "in the Northern region, the minimum number of dental surgeons working in the family health strategy does not meet the needs of the population" (North, specialist 280), as well as "having an oral health team in the municipality of residence" (Midwest, specialist 46).

In the general health dimension, the variable chronic diseases was highlighted to define vulnerability: "cardiopathies, smoking, diabetes, and hypertension" (specialist 29, Southeast), "large number of patients with hypertension (HTN), diabetes 
mellitus (DM), cardiac patients, cancer patients who do not have access to the oral health service due to lack of vacancies, or due to lack of knowledge of the need for monitoring and/or treatment" (specialist 259, South).

In the mental health dimension, all regions showed concern and a relation between depression and the effect of patients' mental conditions on their general health. The following factors were cited: "Deficient nutrition, affected immune system, psychiatric disorder, chronic diseases, bedridden patient" (Southeast, specialist 247); "Neurological problems" (Northeast, specialist 213); "Depression" (Midwest, specialist 109), "Low self-esteem, irritability, resentment, sadness" (specialist 250, South). In addition, fear of dentist was widely quoted: "Aversion to dental equipment" (specialist 91, Northeast) and "Fear of dentist, the association with pain, and the culture of "if the tooth hurts, pull it out" (specialist 77, Southeast).

In the oral health dimension, some factors showed the inequities in dentistry through the items "not believing that dental diseases are avoidable" and "not being responsible for their own oral health." Other more classic factors of dentistry were also considered: "xerostomia and use of drugs that reduce salivary flow" and "regular access to fluoridated tooth paste" (specialist 165, Southeast), as well as "early loss of permanent teeth culminating in the use of poorly adapted prosthesis or absence of teeth" (Northeast, specialist 167).

Moving on to the health services dimension, the following were highlighted: access to basic care and health services, access to dental services, medical insurance, and the scope of oral health teams in relation to family health. According to participant 81 from the Southeast region, "the low assistance coverage" affects the population's health conditions.

In the public management dimension, these factors were presented: corruption, neglect of public management, lack of commitment from the authorities, poor management, precariousness, and lack of investment in education. Added to this, the participants mentioned "lack of resources in public services" (Southeast, specialist 182), "poor management, corruption, lack of basic supplies at the primary care units, such as gloves, anesthetics, medications, etc." (Southeast, specialist 246)

\section{Discussion}

The dental vulnerability pointed out by the participants is composed of social dimensions, infrastructure, general health, oral health, mental health, health services, and public management.

The items income and access to information on oral health are in line with the literature, where economic crises reduce social protection and resources, changing social determinants and population health conditions (Probst et al., 2019). The low socioeconomic conditions are related to higher risks of oral health morbidities, justifying being considered in dental vulnerability (Verlinden, Reijneveld, Lanting, Van Wouwe, \& Schuller, 2019).

Despite the launch of the current National Dental Health Policy (Brasil. Ministerio da Saúde., 2004) and the consequent expansion of the offer of dental services, there is still a shortage of access with the consequent oral morbidities, corroborating the item "access to dental services in the last year" as an important factor of dental vulnerability (Filho et al., 2019).

Access to health information as a vulnerability factor is demonstrated by the relation between low schooling level and poor oral health outcomes (Oliveira et al., 2019; Probst et al., 2019). This enables the development of organizational practices sensitive to this fact, allowing health services to provide subsidies for better health literacy and self-care in oral health (Bado, Rebustini, Jamieson, Cortellazzi, \& Mialhe, 2018; Tomar et al., 2019). It is important to note that although the item "school attendance" has been barely mentioned among participants, other studies have shown its relation with vulnerability (Ribeiro \& Vóvio, 2017; Silva, Pádua, \& Guimarães, 2019).

It is also necessary to consider that the individual's perception of their health influences the search for services and the adherence to self-care measures. The results of the national oral health epidemiological survey conducted in 2010 , known as 
SB Brasil 2010 (J. L. de Sousa, Henriques, da Silva, Severo, \& Silva, 2019), showed that 58.2\% of the adult population (31-44 years) residing in the Midwest region has a positive perception of their oral health. In view of this, the participants considered the item "being ashamed of appearance related to teeth" as important to define vulnerability in that territory, added to selfperception or negative perceived need of the users (validated as an instrument of need for dental treatment), which can lead to oral health morbidity outcomes (Dalazen, Bomfim, \& De-Carli, 2018).

Although factors such as income and access to oral health information appear to be relevant to dental vulnerability, in the South region, the variables "having had a toothache" and "access to a toothbrush" were predominant, reflecting the impact of oral problems on people, often translated by pain, impairment of function, and quality of life (Oliveira et al., 2019).

Regarding health organizations and how they deal with mitigating vulnerabilities, "access to dental service in the last year" is important in view of equity, since studies have shown that most of the poorest do not go to a dental service annually, and have the highest risks of morbidity in oral health (Barros \& Bertoldi, 2002; Stopa et al., 2017).

In addition, participants reported "difficulty in integrating oral health with the rest of the primary care team at Primary Care Units (PCU)," suggesting a distance in the work process that may compromise access and the offer of assistance to users.

The action of primary care teams in the most deprived regions of Brazil, and the relation between these needs and oral health morbidity outcomes are already known. There is a tendency of their coverage to grow in all regions and in most states, considering that São Paulo and the Federal District were the ones with the lowest coverage of less than 50\% (Dalazen et al., 2018; Paim et al., 2011; Palacio et al., 2014).

According to SB Brasil 2010, 25.8\% of children up to 12 years in the Northeast have never been to the dentist, added to 16\% of 16-year-old adolescents and 8\% of adults aged 35 to 44 years (Brasil. Ministério da Saúde., 2010). These may be vulnerability factors, since in areas of greater need, a large number of users with oral morbidities and low population coverage are reflected.

Health inequities are present throughout the Brazilian territory and it is understood that infrastructure factors and health outcomes are interconnected. However, they are dependent on effective care management that is related to macrosocial situations and to what extent they impact individual fragilities in facing vulnerable situations (Carmo \& Guizardi, 2018).

Some factors indicated as potential dental vulnerability, such as access to a toothbrush (53.2\%), dental floss (33.7\%), toothache (50\%), and diabetes (36.7\%) are related to the main morbidities in oral health. However, they are also affected by contextual issues, such as income and education, reflecting the interdependence between the factors (J. N. L. de Sousa, Nóbrega, \& ArakiI, 2014).

Thus, this study presents a concept of dental vulnerability that considers the social, structural, general, mental, and oral health dimensions, as well as factors that involve health services and public management as influential in the dynamics of the health-disease process in dentistry.

\section{Conclusion}

Dental vulnerability has been conceived as a set of factors of the social, structural, and general, mental, oral health dimensions, in addition to health services and public management that influence the dynamics of the health-disease process in dentistry.

The methodological procedures and the scope of the research allowed the inclusion of the different perceptions of all regions of Brazil, respecting their peculiarities, and observing how this concept has been understood in different populations.

The results found will enable the advancement of new studies on this subject and the development of instruments to measure the phenomenon, and thus assist in planning and prioritizing oral health actions in the territory. 


\section{Contribution of authors}

Palacio DC contributed with conception and design of the study, data analysis and interpretation, text writing, critical review, editing and approval of the final manuscript. Rebustini F contributed with conception and design of the study, data analysis and interpretation, critical review, and approval of the final manuscript. De Oliveira DB contributed with data interpretation, text writing, critical review, editing and approval of the final manuscript. Neto JP and Sanchez TP contributed with data interpretation, text writing, and approval of the final manuscript. Mafra ACCN, Bonfim D and Miraglia JL contributed with data analysis and interpretation, text writing, critical review, editing and approval of the final manuscript. Bado FMR contributed with conception and design of the study, editing and approval of the final manuscript. Barbieri W, Filho VVG contributed with text writing, and approval of the final manuscript. Pereira AC contributed with conception and design of the study, data interpretation, text writing, critical review, editing and approval of the final manuscript. All authors approved the final version and are responsible for all aspects of the work, including assurance of its precision and integrity.

\section{References}

Ayres, J. R. de C. M., Calazans, G. J., Filho, H. C. S., \& França-Júnior, I. (2003). O risco, vulnerabilidade e práticas de prevenção e promoção da saúde. Saúde em debate, (170), 375-417.

Bado, F. M. R., Rebustini, F., Jamieson, L., Cortellazzi, K. L., \& Mialhe, F. L. (2018). Evaluation of the psychometric properties of the Brazilian version of the Oral Health Literacy Assessment in Spanish and development of a shortened form of the instrument. PLoS ONE, 13(11), e0207989.

Bardin, L. (1977). Análise de Conteúdo (2010th ed.). v.70.

Barros, A. J. D., \& Bertoldi, A. D. (2002). Desigualdades na utilização e no acesso a serviços odontológicos: uma avaliação em nível nacional. Ciência \& Saúde Coletiva, 7(4), 709-17. ABRASCO - Associação Brasileira de Saúde Coletiva.

Brasil. Ministério da Saúde. (2004). Diretrizes da Política Nacional de Saúde Bucal. Secretaria de Atenção à Saúde. Departamento de Atenção Básica. Coordenação Nacional de Saúde Bucal. Brasilia - DF. http://189.28.128.100/dab/docs/publicacoes/geral/diretrizes_da_politica_nacional_de_saude_bucal.pdf

Brasil. Ministério da Saúde. (2010). SB Brasil 2010 Pesquisa Nacional de Saude Bucal - Resultados Principais. https://bvsms.saude.gov.br/bvs/publicacoes/pesquisa_nacional_saude_bucal.pdf

Bulgareli, J. V., De Faria, E., Cortellazzi, K. L., Guerra, L. M., Meneghim, M. de C., Ambrosano, G. M. B., Frias, A. C., et al. (2018). Fatores que influenciam o impacto da saúde bucal nas atividades diárias de adolescentes, adultos e idosos. Revista de Saúde Pública, 52:44.

Carmo, M. E. do, \& Guizardi, F. L. (2018). O conceito de vulnerabilidade e seus sentidos para as políticas públicas de saúde e assistência social. Cadernos de Saúde Pública, 34(3), e00101417.

Dalazen, C. E., Bomfim, R. A., \& De-Carli, A. D. (2018). Fatores associados à autopercepção da necessidade de tratamento odontológico e de prótese em idosos brasileiros. Ciência \& Saúde Coletiva, 23(3), 945-952. ABRASCO - Associação Brasileira de Saúde Coletiva.

Dimenstein, M., \& Cirilo Neto, M. (2020). Abordagens conceituais da vulnerabilidade no âmbito da saúde e assistência social. Pesquisas e Práticas Psicossociais, 15(1), 1-17. http://www.seer.ufsj.edu.br/index.php/revista_ppp/article/view/3704/2312

Filho, V. V. G., Gondinho, B. V., Silva-Junior, M. F., Cavalcante, D. de F. B., Bulgareli, J. V., De Souza, M. da L. R., Frias, A. C., et al. (2019). Perdas dentárias em adultos: fatores associados à posição e ao número de dentes perdidos. Revista de Saúde Pública, 53(105).

Da Fonseca, Emílio P., Frias, A. C., Mialhe, F. L., Pereira, A. C., \& Meneghim, M. de C. (2017). Factors associated with last dental visit or not to visit the dentist by Brazilian adolescents: A population-based study. PLoS ONE, 12(8), e0183310.

Fonseca, Emílio Prado da, Fonseca, S. G. O. da, \& Meneghim, M. D. C. (2017). Análise do acesso aos serviços odontológicos públicos no Brasil. ABCS Health Sciences, 42(2).

Goodman, L. A. (1961). Snowball Sampling. The Annals of Mathematical Statistics, 32(1), 148-170. Institute of Mathematical Statistics.

Korstjens, I., \& Moser, A. (2018). Series: Practical guidance to qualitative research. Part 4: Trustworthiness and publishing. European Journal of General Practice, 24(1), 120-4.

Loh, L. W. (2017). The Importance of Recognizing Social Vulnerability in Patients during Clinical Practice. J Health Care Poor Underserved, 28(3), 869880 .

Oliveira, R. F. R., Haikal, D. S., Ferreira, R. C., Santos, A. S. F., Nascimento, J. E., Soares, J. R. D., Ferreira, E. F. e, et al. (2019). Abordagem multinível quanto ao uso de serviços odontológicos no Sistema Único de Saúde entre adultos brasileiros. Cadernos Saúde Coletiva, $27(4), 455-67$.

Paim, J., Travassos, C., Almeida, C., Bahia, L., \& Macinko, J. (2011). The Brazilian health system: history, advances, and challenges. Lancet (London, England), 377(9779), 1778-97. Elsevier. http://www.ncbi.nlm.nih.gov/pubmed/21561655 
Palacio, D. da C., Vazquez, F. de L., Ramos, D. V. R., Peres, S. V., Pereira, A. C., Guerra, L. M., Cortellazzi, K. L., et al. (2014). Evolution of postdeployment indicators of oral health on the Family Health Strategy. Einstein (São Paulo, Brazil), 12(3), 274-81.

Peres, M. A., Macpherson, L. M. D., Weyant, R. J., Daly, B., Venturelli, R., Mathur, M. R., Listl, S., et al. (2019). Oral diseases: a global public health challenge. The Lancet, 394(10194), 249-260. Erratum in: Lancet. 2019;394(10203):1010. Elsevier Ltd.

Probst, L. F., Pucca Junior, G. A., Pereira, A. C., De Carli, A. D., Carli, A. D. De, \& De-Carli, A. D. (2019). Impacto das crises financeiras sobre os indicadores de saúde bucal: revisão integrativa da literatura. Ciência \& Saúde Coletiva, 24(12), 4437-4448. Associacao Brasileira de Pos - Graduacao em Saude Coletiva. http://www.scielo.br/scielo.php?script=sci_arttext\&pid=S1413-81232019001204437\&tlng=pt

Pucca Junior, G. A., Gabriel, M., Almeida Carrer, F. C. de, Paludetto Junior, M., Lucena, E. H. G. de, \& Melo, N. S. de. (2020). Acesso e cobertura populacional à saúde bucal após a implantação da Política Nacional de Saúde Bucal "Brasil Sorridente." Tempus Actas de Saúde Coletiva, 14(1), 29-43. Nucleo de Estudos em Saude Publica. http://tempusactas.unb.br/index.php/tempus/article/view/2629

Ribeiro, V. M., \& Vóvio, C. L. (2017). Desigualdade escolar e vulnerabilidade social no território. Educar em Revista, Edição Esp, 71-87.

Silva, M. T. G., Pádua, P. M. R., \& Guimarães, M. de O. (2019). Os impactos de experiências de contextos de vulnerabilidade social sobre os processos de aprendizagem: o aluno entre o enjeitamento e a escola. Revista do Instituto de Ciências Humanas, 15(21), 59-80.

de Sousa, J. L., Henriques, A., da Silva, Z. P., Severo, M., \& Silva, S. (2019). Socioeconomic position and self-rated oral health in Brazil: Results of the brazilian national health survey. Cadernos de Saude Publica, 35(6), e00099518. Fundacao Oswaldo Cruz.

Sousa, J. N. L. de, Nóbrega, D. R. de M., \& ArakiI, Â. T. (2014). Perfil e percepção de diabéticos sobre a relação entre diabetes e doença periodontal. Revista de Odontologia da UNESP, 43(4), 265-272.

Stopa, S. R., Malta, D. C., Monteiro, C. N., Szwarcwald, C. L., Goldbaum, M., \& Cesar, C. L. G. (2017). Use of and access to health services in Brazil, 2013 National Health Survey. Revista de Saude Publica, 51, 1S-10S. Universidade de Sao Paulo.

Tomar, D., Menon, I., Singh, A., Tyagi, U., Passi, D., \& Goyal, J. (2019). Comparative study of risk indicators associated with tooth loss among adult population in urban and rural areas of Muradnagar, Ghaziabad, Uttar Pradesh, India. Journal of Family Medicine and Primary Care, 8(2), 528-34. Wolters Kluwer -- Medknow Publications.

Verlinden, D. A., Reijneveld, S. A., Lanting, C. I., Van Wouwe, J. P., \& Schuller, A. A. (2019). Socio-economic inequality in oral health in childhood to young adulthood, despite full dental coverage. European Journal of Oral Sciences, 127(3), 248-53. John Wiley \& Sons, Ltd (10.1111).

Watt, R. G., Venturelli, R., \& Daly, B. (2019). Understanding and tackling oral health inequalities in vulnerable adult populations : from the margins to the mainstream. British Dental Journal, 227(1), 49-54. 